\title{
Assessment of groundwater quality for drinking and irrigation purposes using hydrochemical studies in Malwa region, southwestern part of Punjab, India
}

\author{
Tajinder Kaur $^{1} \cdot$ Renu Bhardwaj $^{1} \cdot$ Saroj Arora $^{1}$
}

Received: 9 June 2016/Accepted: 8 September 2016/Published online: 6 October 2016

(c) The Author(s) 2016. This article is published with open access at Springerlink.com

\begin{abstract}
Deterioration of groundwater quality due to anthropogenic activities is increasing at an alarming rate in most parts of the Punjab, but limited work has been carried out on groundwater quality and monitoring. This paper highlights the groundwater quality and compares its suitability for drinking and irrigation purpose in Malwa region, a southwestern part of Punjab. The Malwa region makes up the most cultivated area of Punjab with high consumption of pesticides and fertilizers. Twenty-four water samples representing groundwater sources were collected and analyzed for almost all major cations, anions and other physicochemical parameters. Analytical results of physicochemical analysis showed majority of the samples above the permissible limits of the Indian standards. The groundwater of the study area was very hard and the relative abundance of major cations and anions was $\mathrm{Na}^{+}>\mathrm{Ca}^{2+}>\mathrm{Mg}^{2+}>\mathrm{K}^{+}$and $\mathrm{HCO}_{3}{ }^{-}>\mathrm{SO}_{4}{ }^{2-}>\mathrm{Cl}^{-}$. Fluoride content was higher than permissible limit in $75 \%$ of the samples. The mean concentration of arsenic in groundwater was 9.37 and $11.01 \mu \mathrm{g} / \mathrm{L}$ during summer and winter season, respectively. The parameters like sodium adsorption ratio and sodium percentage $(\mathrm{Na} \%)$ revealed good quality of groundwater for irrigation purposes, whereas magnesium ratio and corrosivity ratio values showed that water is not suitable for agriculture and domestic use. The dominant hydrochemical facies of groundwater was $\mathrm{Ca}-\mathrm{Mg}-\mathrm{HCO}_{3}$ and $\mathrm{Ca}-\mathrm{Mg}-\mathrm{SO}_{4}-\mathrm{Cl}$. Chloro alkaline indices 1 and 2 indicated that reverse ion exchange is dominant in the region. The samples fall in
\end{abstract}

Saroj Arora

sarojarora.gndu@gmail.com

1 Department of Botanical and Environmental Sciences, Guru Nanak Dev University, Amritsar 143005, India rock dominance and evaporation dominance fields as indicated by Gibbs diagram. The saturation index shows that all the water samples were supersaturated with respect to carbonate minerals. This work thus concludes that groundwater in the study area is chemically unsuitable for domestic and agricultural uses. It is recommended to carry out a continuous water quality monitoring program and development of effective management practices for utilization of water resources.

Keywords Groundwater - Arsenic · Drinking and irrigation water quality $\cdot$ Malwa region $\cdot$ Punjab $\cdot$ India

\section{Introduction}

Due to rapid industrialization and increasing human population, the stress on natural resources is increasing and their conservation is one of the major challenges for mankind. Groundwater is a most vital resource for millions of people for both drinking and irrigation. The quality of groundwater is as important as its quantity because it is the major factor in determining its suitability for drinking, domestic, irrigation and industrial purposes. The concentration of chemical constituents which is greatly influenced by geological formations and anthropogenic activities determine the groundwater quality. Both the agricultural and anthropogenic activities have resulted in deterioration of water quality rendering serious threats to human beings. The quality of groundwater cannot be restored once it is contaminated. Fluoride occurs naturally in groundwater and provides protection against dental caries, especially in children. But the fluoride concentration less than $0.5 \mathrm{mg} / \mathrm{L}$ leads to the risk of tooth decay while higher concentration causes dental fluorosis (Thivya et al. 2015). Nitrate 
concentration above $45 \mathrm{mg} / \mathrm{L}$ may prove harmful to human health causing methemoglobinemia (blue babies) which generally affects bottle-fed infants (Jain et al. 2010). High concentration of sulfates may induce diarrhea and intestinal disorders. Elevated concentrations of $\mathrm{Fe}$ in natural water resources can lead to several serious health problems like cancer, diabetes, liver and heart diseases as well as neurodegenerative diseases (Azizullah et al. 2011). Arsenic in drinking water is related to occurrence of skin lesions (Chakraborti et al. 2016).

Punjab, a northwestern state of India is one of the 29 states in the country with an area of $50,362 \mathrm{~km}^{2}$, which is about $1.6 \%$ of the total geographical area of the country (Thakur et al. 2016). The groundwater is predominately used for irrigation and drinking purpose in the rural areas of Punjab. The quality of groundwater in southwestern districts of Punjab is deteriorating due to anthropogenic pollution including excessive use of fertilizers and pesticides. The worst example of agriculture based pollution is the contamination of groundwater and drinking water with uranium in the Malwa region of Punjab. According to a report entitled 'Water Logging in Punjab by Planning Commission', Government of India (2013), a considerable area of the southern and southwestern part of the state has nitrate concentration exceeding the critical level. High fluoride content, i.e., more than $10 \mathrm{mg} / \mathrm{L}$ has been found in Fazilka, Muktsar, Bathinda, Sangrur, Barnala districts. The Muktsar district of Punjab is facing a severe problem of water logging and salinization. According to Central Ground Water Board (2007), the groundwater in Bathinda is alkaline in nature, moderately to highly saline and contains high concentration of fluoride. Hundal et al. (2007) reported arsenic concentrations greater than the safe limits in water samples from southwest zone of Punjab. Recently, there has been an alarming increase in the number of cancer cases in southwestern districts of Punjab. But a comprehensive report on quality of groundwater in the study area is not available, although much of its groundwater resources are contaminated. Moreover, the data comprising the water quality monitoring consists of regular measurements of physicochemical parameters to understand the geochemistry of water and its suitability for domestic and agriculture uses. The quality of water for irrigation is determined by the concentration and composition of dissolved ions which are generally governed by lithology of subsurface, velocity and quantity of groundwater flow, nature of geochemical reactions, solubility of salts and various anthropogenic activities (Tamma et al. 2015). This study is an attempt in this direction, and evaluates the chemical characteristics and the principal hydrochemical processes controlling groundwater hydrochemistry in major agricultural parts of Malwa region with dense agricultural activities. The results of the study will be useful in the sustainable management of groundwater resources in the region.

\section{Materials and methods}

\section{Study area}

Major part of the study area is located in Malwa region of Punjab, India between $29^{\circ} 30^{\prime}$ and $31^{\circ} 10^{\prime}$ North latitudes and $73^{\circ} 50^{\prime}$ and $76^{\circ} 50^{\prime}$ East longitudes (Table 1). It is bounded by the River Sutlej in the north, Haryana in the east and the south, Rajasthan in the southwest corner, and by Bahawalpur State of Pakistan in the west. The Malwa area makes up the majority of the Punjab region and has the most fertile land. The main economic activity in the area is agriculture, with the chief crops being cotton and rice. It is commonly known as the cotton belt of Punjab. The two crops are known for excessive use of pesticides. Climate of Malwa is comparatively hot, dry and arid. Three distinct seasons are experienced, viz, winter, summer and monsoon. There is a large seasonal fluctuation of both temperature and rainfall. Summers are extremely hot while winters are cold. The annual temperature varies between 2 and $45{ }^{\circ} \mathrm{C}$. The area is also swept by dust storms during the summer. Average annual rainfall in this zone is about $420 \mathrm{~mm}$. The soil of the study area is loose, sandy, calcareous and alluvial, which is an admixture of gravel, sand, silt and clay in varying proportions (Bajwa et al. 2015). Physiographically, the region has about flat to undulating geography and little patches of sand dunes.

\section{Water analysis}

The map of Malwa region of Punjab was prepared and gridding was done to carry out systematic collection of water samples. Groundwater samples were collected from 24 locations of the study area using Global Positioning System (GPS) during the month of June 2013 and February 2014. The samples were collected after $10 \mathrm{~min}$ of pumping and stored in good quality polythene bottles of $1 \mathrm{~L}$ capacity previously soaked in $10 \%$ nitric acid $\left(\mathrm{HNO}_{3}\right)$ for $24 \mathrm{~h}$ and rinsed with deionized water. The water samples collected for arsenic analysis were filtered and acidified with few drops of $\mathrm{HNO}_{3}$. All samples were transported to the laboratory and kept at $4{ }^{\circ} \mathrm{C}$ until used for further analysis. Water temperature, $\mathrm{pH}$, electrical conductivity (EC), total dissolved solids (TDS) and turbidity were measured in the field using ELICO water quality analyzer PE 138. The samples were analyzed in triplicates for their chemical constituents in accordance to "standard methods for the examination of water and waste water American Public Health Association (APHA 1985)". Total alkalinity (as 
Table 1 Sampling locations in Malwa region of Punjab

\begin{tabular}{|c|c|c|c|c|}
\hline Sr. no. & Sampling location & District & Longitude (E) & Latitude $(\mathrm{N})$ \\
\hline 1. & Bajakhana (GWS1) & Faridkot & $74^{\circ} 98^{\prime} 50.7^{\prime \prime}$ & $30^{\circ} 46^{\prime} 06.9^{\prime \prime}$ \\
\hline 2. & Ramiana (GWS2) & Faridkot & $74.7^{\circ} 8^{\prime} 55.3^{\prime \prime}$ & $30^{\circ} 42^{\prime} 00.5^{\prime \prime}$ \\
\hline 3. & Sotha (GWS3) & Muktsar & $74.5^{\circ} 5^{\prime} 41.3^{\prime \prime}$ & $30^{\circ} 38^{\prime} 25.7^{\prime \prime}$ \\
\hline 4. & Ballamgarh (GWS4) & Muktsar & $74.4^{\circ} 3^{\prime} 55.0^{\prime \prime}$ & $30^{\circ} 46^{\prime} 44.6^{\prime \prime}$ \\
\hline 5. & Sarawan Bodla (GWS5) & Muktsar & $74.3^{\circ} 9^{\prime} 82.7^{\prime \prime}$ & $30^{\circ} 21^{\prime} 72.7^{\prime \prime}$ \\
\hline 6. & Gurusar Jodheke (GWS6) & Muktsar & $74.3^{\circ} 8^{\prime} 88.7^{\prime \prime}$ & $30^{\circ} 14^{\prime} 95.3^{\prime \prime}$ \\
\hline 7. & Deon Khera (GWS7) & Muktsar & $74.5^{\circ} 0^{\prime} 88.5^{\prime \prime}$ & $30^{\circ} 10^{\prime} 06.2^{\prime \prime}$ \\
\hline 8. & Lambi (GWS8) & Muktsar & $74.6^{\circ} 0^{\prime} 92.1^{\prime \prime}$ & $30^{\circ} 05^{\prime} 62.5^{\prime \prime}$ \\
\hline 9. & Bandi (GWS9) & Muktsar & $74.7^{\circ} 6^{\prime} 02.2^{\prime \prime}$ & $30^{\circ} 06^{\prime} 01.1^{\prime \prime}$ \\
\hline 10. & Balluana (GWS10) & Bathinda & $74.7^{\circ} 9^{\prime} 20.5^{\prime \prime}$ & $30^{\circ} 21^{\prime} 58.5^{\prime \prime}$ \\
\hline 11. & Shergarh (GWS11) & Bathinda & $74.9^{\circ} 5^{\prime} 77.1^{\prime \prime}$ & $30^{\circ} 08^{\prime} 44.5^{\prime \prime}$ \\
\hline 12. & Talwandi Sabo (GWS12) & Bathinda & $75.0^{\circ} 8^{\prime} 37.3^{\prime \prime}$ & $29^{\circ} 99^{\prime} 08.2^{\prime \prime}$ \\
\hline 13. & Bathinda (GWS13) & Bathinda & $74.9^{\circ} 6^{\prime} 04.2^{\prime \prime}$ & $30^{\circ} 18^{\prime} 35.7^{\prime \prime}$ \\
\hline 14. & Bhucho Mandi (GWS14) & Bathinda & $75.0^{\circ} 8^{\prime} 85.2^{\prime \prime}$ & $30^{\circ} 20^{\prime} 87.2^{\prime \prime}$ \\
\hline 15. & Kotha Guru (GWS15) & Bathinda & $75.0^{\circ} 9^{\prime} 28.3^{\prime \prime}$ & $30^{\circ} 43^{\prime} 52.4^{\prime \prime}$ \\
\hline 16. & Dialpura Bhaika (GWS16) & Bathinda & $75.2^{\circ} 0^{\prime} 36.1^{\prime \prime}$ & $30^{\circ} 48^{\prime} 24.5^{\prime \prime}$ \\
\hline 17 & Rampura Phul (GWS17) & Bathinda & $75.2^{\circ} 3^{\prime} 10.3^{\prime \prime}$ & $30^{\circ} 27^{\prime} 76.9^{\prime \prime}$ \\
\hline 18. & Maur mandi (GWS18) & Bathinda & $75.2^{\circ} 2^{\prime} 23.3^{\prime \prime}$ & $30^{\circ} 07^{\prime} 16.3^{\prime \prime}$ \\
\hline 19. & Behniwal (GWS19) & Mansa & $75.1^{\circ} 9^{\prime} 34.7^{\prime \prime}$ & $29^{\circ} 93^{\prime} 12.6^{\prime \prime}$ \\
\hline 20. & Nangal Khurd (GWS20) & Mansa & $75.3^{\circ} 7^{\prime} 21.7^{\prime \prime}$ & $29^{\circ} 94^{\prime} 64.7^{\prime \prime}$ \\
\hline 21. & Burj Harike (GWS21) & Mansa & $75.3^{\circ} 8^{\prime} 60.0^{\prime \prime}$ & $30^{\circ} 08^{\prime} 05.9^{\prime \prime}$ \\
\hline 22. & Pakho Kalan (GWS22) & Barnala & $75.4^{\circ} 1^{\prime} 66.7^{\prime \prime}$ & $30^{\circ} 21^{\prime} 69.2^{\prime \prime}$ \\
\hline 23. & Dhilwan (GWS23) & Barnala & $75.3^{\circ} 8^{\prime} 10.3^{\prime \prime}$ & $30^{\circ} 32^{\prime} 38.9^{\prime \prime}$ \\
\hline 24. & Ramgarh (GWS24) & Barnala & $75.3^{\circ} 9^{\prime} 46.6^{\prime \prime}$ & $30^{\circ} 51^{\prime} 53.8^{\prime \prime}$ \\
\hline
\end{tabular}

$\left.\mathrm{HCO}_{3}\right)$ was determined by acid titration method $(0.1 \mathrm{~N}$ $\mathrm{HCl}$ ) using methyl orange as an indicator. The total hardness $(\mathrm{TH})$ and calcium $(\mathrm{Ca})$ of water was analyzed volumetrically by ethylene diamine tetra acetic acid (EDTA, $0.01 \mathrm{M})$ titration method using Eriochrome Black T and Murexide indicators, respectively. The magnesium $(\mathrm{Mg})$ concentration is calculated by subtracting concentration of $\mathrm{Ca}$ from total concentration of $\mathrm{Ca}$ and $\mathrm{Mg}$. Concentration of chloride $(\mathrm{Cl})$ was determined by Argentometric method by titrating against silver nitrate solution $\left(\mathrm{AgNO}_{3}\right.$, $0.014 \mathrm{~N}$ ). SPADNS calorimetric method was employed to measure the concentration of fluoride. Sulfates were measured by turbidimetric method as $\mathrm{BaSO}_{4}$ while phosphates were determined by stannous chloride method. Nitrate $\left(\mathrm{NO}_{3}{ }^{-}\right)$concentration was estimated using UV-visible spectrophotometer at a wavelength of 220 and $275 \mathrm{~nm}$. The $\mathrm{NO}_{3}{ }^{-}$concentration was measured at $275 \mathrm{~nm}$ to overcome interferences by dissolved organic matter, which also absorbs at $220 \mathrm{~nm}$ while $\mathrm{NO}_{3}{ }^{-}$was not absorbed at $270 \mathrm{~nm}$. The $\mathrm{NO}_{3}{ }^{-}$values were accordingly corrected by subtracting twice the reading at $270 \mathrm{~nm}$ from $220 \mathrm{~nm}$ reading. Concentrations of iron $(\mathrm{Fe})$, sodium $(\mathrm{Na})$ and potassium (K) were measured using Flame Atomic Absorption Spectrophotometer (FAAS) Model 240 FS AA with Single Element Ultra AA Hollow Cathode Lamps. For analysis of arsenic, water sample $(10 \mathrm{~mL})$ was mixed with $5 \mathrm{M}$ hydrochloric acid $(10 \mathrm{~mL})$ followed by the addition of potassium iodide $(1 \mathrm{~mL})$. The arsenic (As) content was determined after 30 min using 240 FS AA unit coupled with VGA 77 Vapor Generation Accessory (200 Series AA, Agilent Technologies, USA) with Single Element Ultra AA Hollow Cathode Lamp (Agilent Technologies, USA) of As. The standards were for As and Fe were prepared from stock solutions of As and Fe procured from Agilent Technologies, USA. The concentration of all the major cations, anions and metals was measured using standard reference solutions of analytical grade. Double distilled water was used for preparing the solutions and blank throughout the analysis. All mathematical calculations like ranges, means and standard deviations were calculated for physico-parameters using Excel 2007 (Microsoft Office). The statistical comparison like correlation analysis was done using SPSS version 16.0. The Piper diagram was plotted using Aquachem software. 


\section{Results and discussions}

\section{Physicochemical analysis}

The summary of the analytical results and the statistical measures such as minimum, maximum, mean and standard deviation is given in Table 2 for June 2013 and February 2014. The $\mathrm{pH}$ of all the groundwater samples of the study area was within the permissible limits while the high turbidity exceeding the desirable levels were observed in most of the samples. High turbidity of water is often associated with high levels of disease causing organisms such as viruses, parasites and bacteria responsible for symptoms such as nausea, cramps and diarrhea (Memon et al. 2016). Among the physicochemical parameters studied, total hardness and alkalinity was found to be much higher than the permissible limits as prescribed by BIS standard. Hardness of water mainly depends upon the amount of calcium or magnesium along with their carbonates, sulfates and chlorides. Based on TH classification of groundwater (Table 5) almost all the samples were found to be very hard and unfit for drinking. Analysis revealed that the total hardness reported in our study was higher as compared to earlier studies (Sharma 2012). The soil texture in the region was predominantly calcareous which may be the possible reason of hardness in water. The order of abundance of the major cations and anions in both the seasons is depicted in Fig. 1. Kumar et al. (2007) also reported $\mathrm{Na}$ as the most dominant cation in the Muktsar district of Punjab, India. The average potassium in the groundwater of the region was found to be $15.32 \mathrm{mg} / \mathrm{L}$ in summer samples which was more as compared to winter samples with an average value of $11.26 \mathrm{mg} /$ L. The agricultural activities may be the main reason of increasing potassium content in groundwater (Sayyed and Bhosle 2011). Both sodium and potassium does not have any prescribed limits for drinking water but the high levels of sodium in drinking water makes it salty in nature. During summer season, $87 \%$ of samples were found to exceed the desirable limit of $\mathrm{Ca}^{2+}$ for drinking water $(75 \mathrm{mg} / \mathrm{L})$. In winter season, the average value of calcium ion was $194.67 \mathrm{mg} / \mathrm{L}$ with maximum value of $502.67 \mathrm{mg} / \mathrm{L}$ observed in sample GSW7. The average value of magnesium was $51.26 \mathrm{mg} / \mathrm{L}$ during summer season which was less as compared to the mean value $(61.40 \mathrm{mg} / \mathrm{L})$ in winter. Mean Ca concentration found in our study were higher than those reported previously in Muktsar groundwater by Kumar et al. (2009) while mean $\mathrm{Mg}$ concentration were found to be lower in this study. Total alkalinity in water is mainly caused due to $\mathrm{OH}, \mathrm{CO}_{3}, \mathrm{HCO}_{3}$ ions. Bicarbonates represent dominant anion in the study area followed by sulfates and chloride. A similar finding was also shown by Thakur et al. (2016) in parts of Punjab which showed that $\mathrm{HCO}_{3}$ as the dominant anion in the region. The highest concentration of sulfates $(692.22 \mathrm{mg} / \mathrm{L})$ was observed in summer water sample (GSW7) collected from Deon Khera area of Muktsar district. High sulfate content may be due to breakdown of organic substances of weathered soils, human activities, use of fertilizers and sulfate leaching (Miller 1979; Craig and Anderson 1979). Maximum allowable limit of sulfate is $400 \mathrm{mg} / \mathrm{L}$. It becomes unstable when this limit exceeds and leads to laxative effect on human system with excess of magnesium (Subramani et al. 2005). Chloride content was within the permissible limits with some $20.8 \%$ samples in summer and $12.5 \%$ samples during winter showed higher concentration of chloride than desirable limit $(250 \mathrm{mg} / \mathrm{L})$ set by BIS for drinking water which may be due to the use of inorganic fertilizers and irrigation drainage. Fluoride occurs as natural constituent and is one of the main trace elements in groundwater. The average of fluoride during summer was $1.971 \mathrm{mg} / \mathrm{L}$ which was above the maximum permissible limit $(1.5 \mathrm{mg} / \mathrm{L})$ as prescribed BIS and WHO. During winter, it varied from 2.98 to $0.81 \mathrm{mg} / \mathrm{L}$. High fluoride content in groundwater is generally linked to the presence of fluoride bearing minerals in aquifers (Handa 1975; Wenzel and Blum 1992). As far as nitrate contamination is concerned, all the samples were below the maximum permissible limit ( $45 \mathrm{mg}$ / L) as prescribed by BIS and WHO. The mean nitrate concentration in the study area was lower as previously reported in Muktsar and Patiala districts of Punjab (Kumar et al. 2007, 2009) but higher than those reported in Jalandhar and Kapurthala districts of Punjab (Purushothman et al. 2012). The average concentration of phosphate in summer samples was more than that of winter samples. Presence of phosphates in groundwater may be attributed to natural minerals or through pollution by application of fertilizer, sewage and industrial waste (Alemu et al. 2015).

\section{Iron and arsenic}

Iron is the second most abundant metal in the earth's crust. Maximum and minimum values of iron are presented in Table 2. About $29 \%$ of the water samples during summer and $50 \%$ of winter water samples contained iron above $0.3 \mathrm{mg} / \mathrm{L}$ (WHO guideline value of iron in drinking water). During summer, the $\mathrm{Fe}$ was found in the range of $0.009-5.41 \mathrm{mg} / \mathrm{L}$ while in winter it ranged from 0.074 to $7.7 \mathrm{mg} / \mathrm{L}$. The mean iron concentration of water samples in the study area were higher than those reported by Bajwa et al. (2015) in SW Punjab $(0.83 \mathrm{mg} / \mathrm{L})$. Figure 2 shows the concentration of arsenic in groundwater of the study area in two different seasons. It was found that about 33 and $75 \%$ samples collected during summer and winter seasons, respectively, has arsenic concentration more than the safe limits of $10 \mu \mathrm{g} / \mathrm{L}$ set by WHO and BIS thus were 


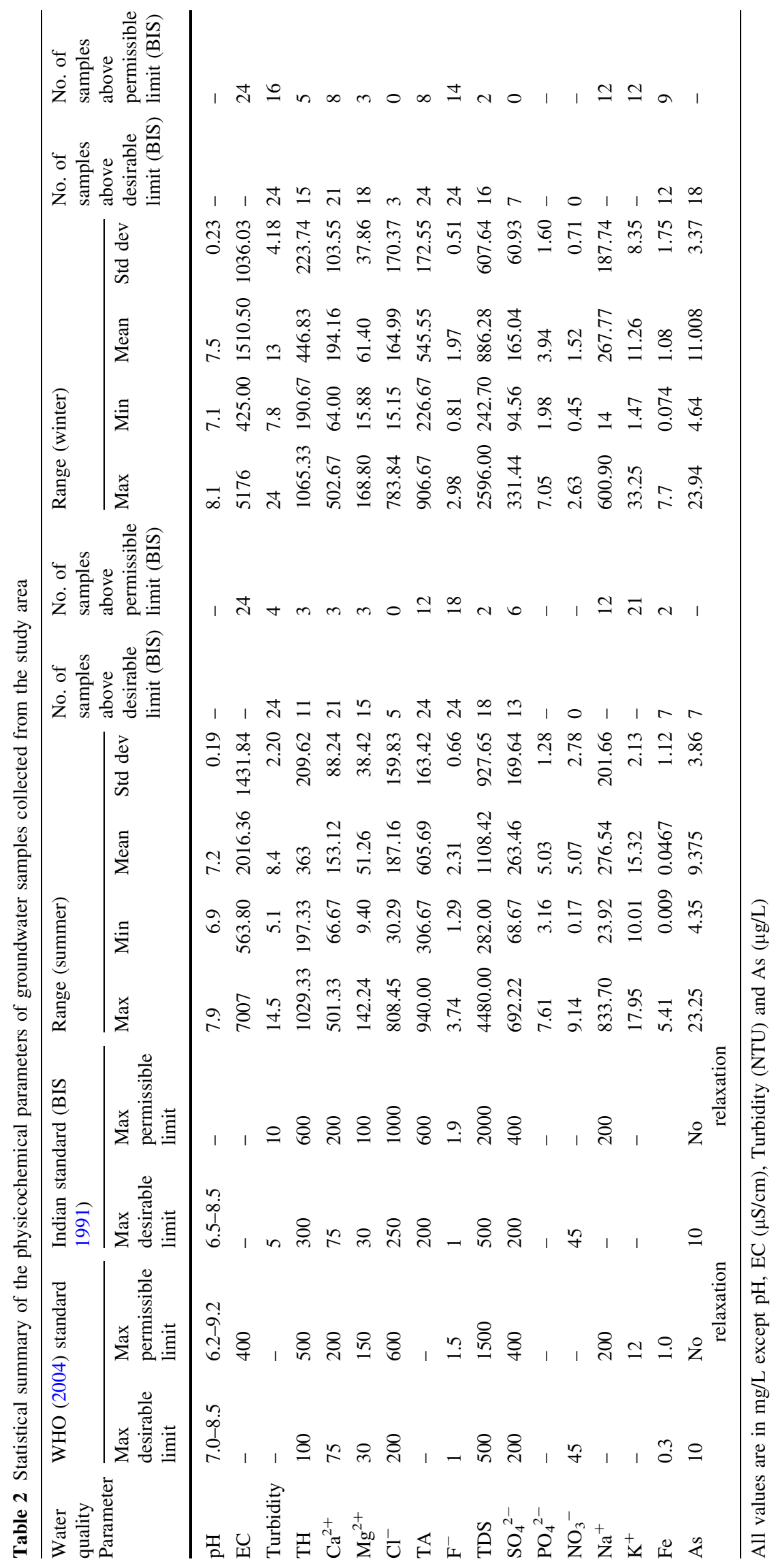




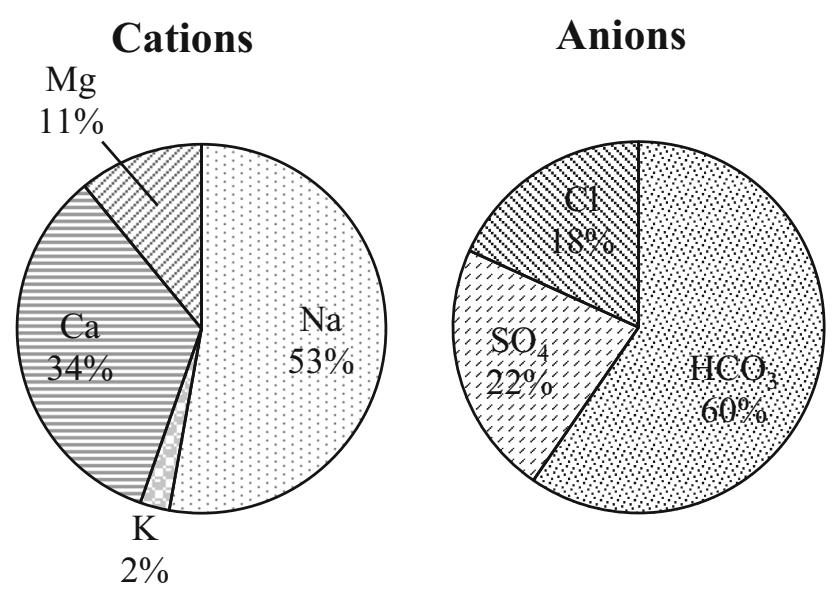

Fig. 1 Pie diagram of mean values of major ions

not suitable for drinking purposes. Mean arsenic concentrations $(10.19 \mu \mathrm{g} / \mathrm{L})$ found in our study were higher than the arsenic concentrations reported previously in Bathinda, (Sharma 2012) and Amritsar (Hundal et al. 2008), but less than the concentrations reported by Sidhu et al. 2014 in southwestern region of Punjab. The elevated levels of arsenic in the study area may be due to its evaporative environment since the climate of this region is arid which can lead to more loss of water by evaporation than its gain by rainfall (Hundal et al. 2007). Arsenic contamination is also strongly associated with high concentrations of iron, phosphate, and ammonium ions, and anthropogenic activities such as excessive groundwater withdrawal for agricultural irrigation (Kumar et al. 2010). Excessive use of arsenical pesticides on crops may be a source of arsenic contamination due to leaching process of fertilizers and pesticides from soils to groundwater. The major source of metal pollution in water is use of pesticides in the form of calcium arsenate, lead arsenate, sodium arsenate and arsenic acid (Rasool et al. 2016).

\section{Correlation analysis}

The correlation matrices for 17 variables were prepared for both summer (Table 3) and winter season (Table 4) using SPSS 16.0. The results of the correlation matrix during summer season were different from that in winter season which showed the significant impact of seasonal variation in the study area. In summer season, a strong correlation between EC-TDS ( $r=0.980), \mathrm{EC}-\mathrm{Cl}(r=0.927), \mathrm{EC}-\mathrm{TH}$
Fig. 2 Mean As concentration in drinking water of the study area

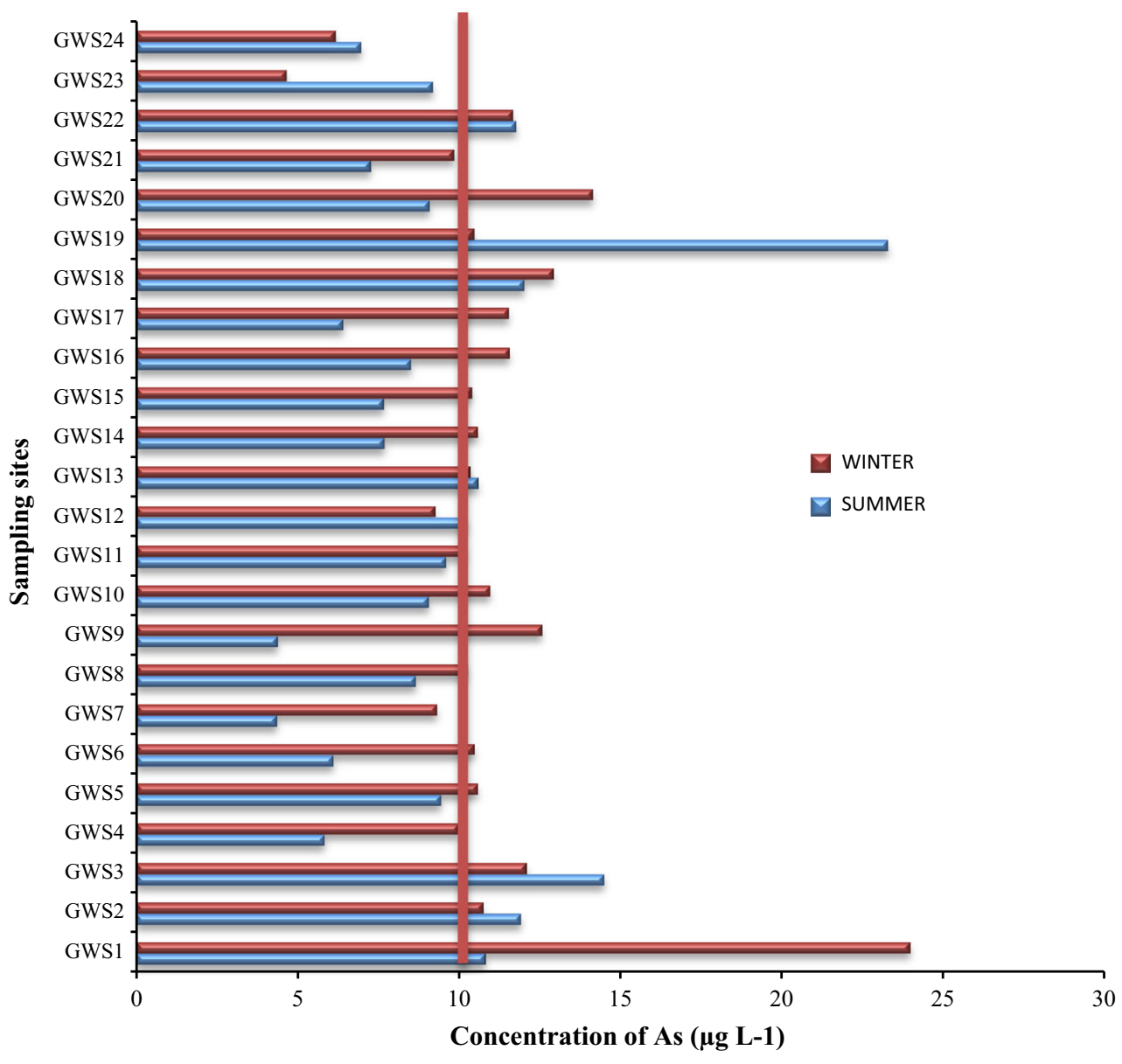




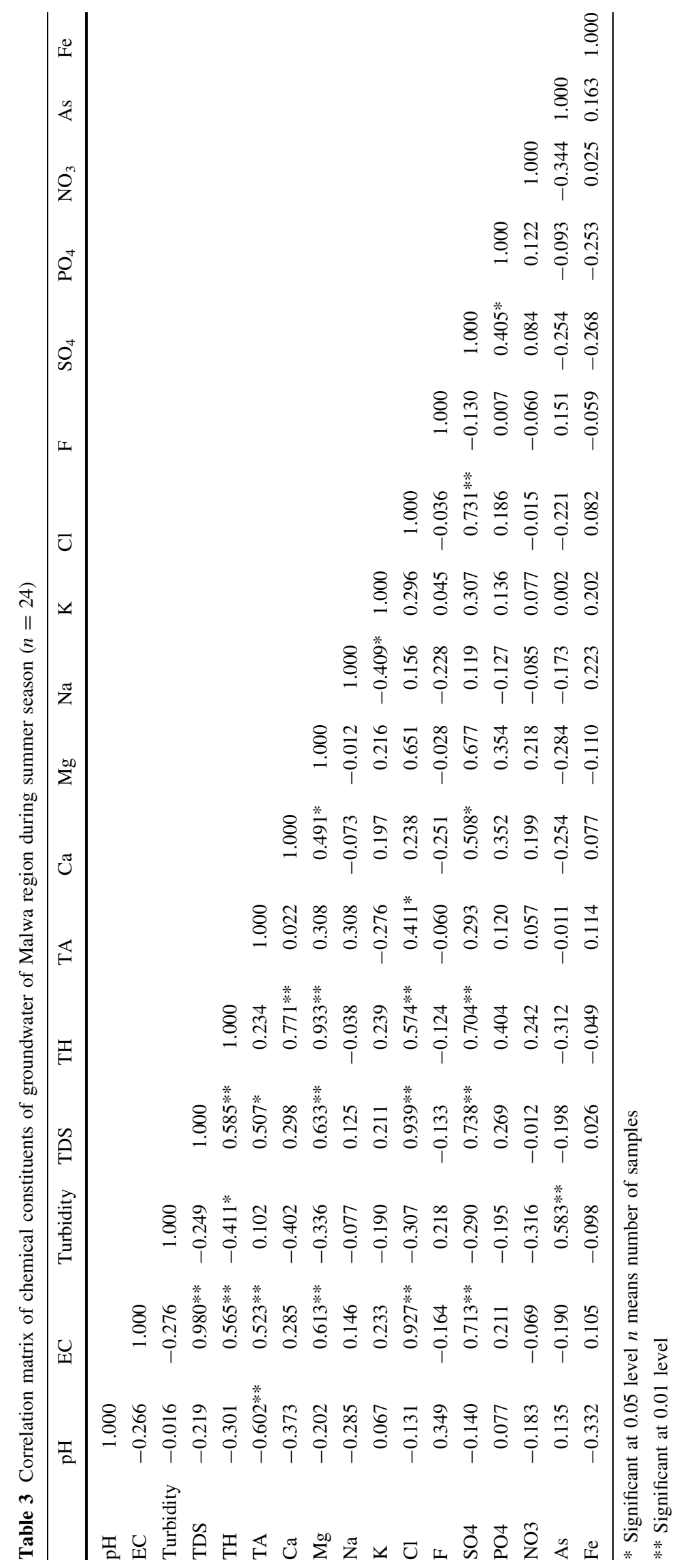




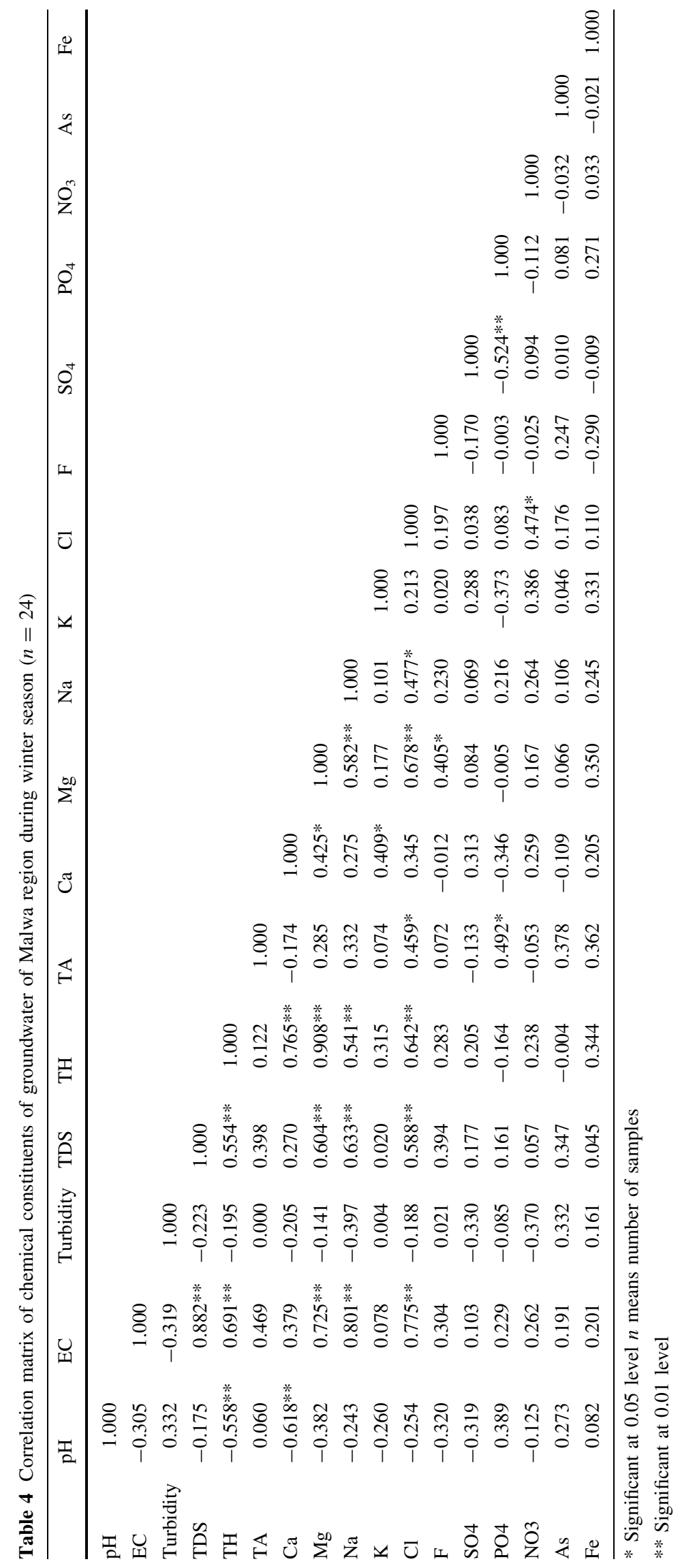


Table 5 Classification of groundwater samples of the study area on the basis of TDS and $\mathrm{TH}$

\begin{tabular}{lllll}
\hline Parameters & Range & Water class & \multicolumn{2}{l}{ No of Samples } \\
\cline { 4 - 5 } & & & Summer & Winter \\
\hline Total hardness (TH) (mg/L) & Soft & $0-60$ & NIL & NIL \\
& Moderately hard & $61-120$ & NIL & NIL \\
& Hard & $121-180$ & 4 & NIL \\
& Very hard & $>180$ & 20 & 24 \\
Total dissolved solid (TDS) (mg/L) & $<1000$ & Nonsaline & 14 & 18 \\
& $1000-3000$ & Slightly saline & 9 & 6 \\
& $3000-10,000$ & Moderately saline & 1 & NIL \\
& $>10,000$ & Very saline & NIL & NIL \\
\hline
\end{tabular}

$(r=0.565), \mathrm{EC}-\mathrm{TA}(r=0.523), \mathrm{EC}-\mathrm{Mg}^{2+}(r=0.613)$, EC-SO ${ }_{4}^{2-}(r=0.713)$, TDS-Mg ${ }^{2+} \quad(r=0.638)$, TDS$\mathrm{SO}_{4}{ }^{2-}(r=0.738)$, TDS-Cl $(r=0.939)$ was observed. This suggested that presence of TH, calcium, sodium, potassium, chloride and sulfate greatly influence the TDS and EC. Besides this, the correlation matrices also shows significant positive correlations between different physicochemical parameters such as $\mathrm{TH}-\mathrm{Ca}^{2+}(r=0.771), \quad \mathrm{TH}-\mathrm{Mg}^{2+}$ $(r=0.933)$, TDS-TH $(r=0.585)$, TH-Cl $(r=0.574)$, TH-SO ${ }_{4}^{2-}(r=0.704)$. This showed that there was great dependence of hardness on calcium, magnesium, chloride and sulfate. Chloride content was significantly and positively correlated with sulfate $(r=0.731)$ and magnesium $(r=0.651)$. A strong positive correlation was observed between $\mathrm{TH}-\mathrm{Mg}^{2+}(r=0.908)$ during winter season. ECTDS, EC-Na and $\mathrm{TH}-\mathrm{Mg}^{2+}$ exhibited correlation of more than 0.8 while EC-TH, EC-Mg ${ }^{2+}, \mathrm{EC}-\mathrm{Cl}$, TDS-TH, TDS$\mathrm{Mg}^{2+}$, TDS-Na, TDS-Cl, TH-Na, TH-Cl, $\mathrm{Mg}^{2+}-\mathrm{Na}$, $\mathrm{Mg}^{2+}-\mathrm{Cl}$ had a correlation varied between 0.4 and 0.8 . Besides a constant correlation between EC-TDS, EC-TH and $\mathrm{EC}-\mathrm{Cl}$ in both the seasons, $\mathrm{K}$ and $\mathrm{F}$ did not show any correlation with any parameters during both the seasons. $\mathrm{pH}$ exhibited a negative correlation with most of the variables in both the seasons. Arsenic does not exhibit any significant correlation with any of the parameters studied except turbidity during summer season. In a similar study conducted by Baig et al. (2009) in groundwater of Jamshoro, Pakistan, a significant correlation between $\mathrm{As}$ and $\mathrm{Fe}$ was observed which indicated that the elevated levels of As might be due to the presence of Fe containing ores. However, no such correlation was observed in this study.

\section{Water quality classification for irrigation}

As the groundwater is being used for irrigation in Malwa region, it is necessary to determine the parameters responsible for irrigation water quality. The important parameters to know the quality of water for irrigation purposes are sodium absorption ratio (SAR), sodium percentage $(\mathrm{Na} \%)$, magnesium ratio $(\mathrm{MR})$ and corrosivity ratio (CR) (Tripathi et al. 2012).

\section{Total dissolved solids and EC}

Total dissolved solids (TDS) in $75 \%$ of the samples during summer and $66 \%$ of the samples during winter season were found to exceed the desirable limit $(500 \mathrm{mg} / \mathrm{L})$ as per Indian standard for drinking water. This may be due to residential waste which migrates down to water table when discharged into pits and ponds (Singh et al. 2010). Based on TDS classification, none of the water samples in both the seasons fall in very saline category and ranged between nonsaline to slightly saline (Table 5). Electrical conductivity (EC) is a good measure of salinity hazard to crops as it reflects the TDS in groundwater. Wide variation in electrical conductivity is observed with minimum value of $563.80 \mu \mathrm{S} / \mathrm{cm}$ and maximum value of $7007 \mu \mathrm{S} / \mathrm{cm}$ with an average value of $2016.36 \mu \mathrm{S} / \mathrm{cm}$ during summer season. During winter, the EC values varied between $425 \mu \mathrm{S} / \mathrm{cm}$ and $5176 \mu \mathrm{S} / \mathrm{cm}$ with an average value of $1516 \mu \mathrm{S} / \mathrm{cm}$. The EC values were observed to be greater in summer season than winter season due to high rate of evaporation during dry season which represents water with high electrolyte concentration (Baig et al. 2009). According to Wilcox (1955) classification, none of the water samples falls in excellent class for irrigation purpose on the basis of salinity hazard (Table 6). Although the majority of the samples fall in permissible range, but still salinity hazard is an issue at few locations. Excess salinity interferes with the absorption of water and nutrients from the soil by reducing the osmotic activity of plants (Saleh et al. 1999).

\section{Sodium adsorption ratio (SAR)}

SAR is a measure of alkali/sodium hazard to crops (Subramani et al. 2005). Excessive amount of sodium relative to $\mathrm{Ca}$ and $\mathrm{Mg}$ inhibits the water supply needed for the 
Table 6 Classification of groundwater samples of the study area for irrigation purposes

\begin{tabular}{|c|c|c|c|c|}
\hline \multirow[t]{2}{*}{ Parameters } & \multirow[t]{2}{*}{ Range } & \multirow[t]{2}{*}{ Classification } & \multicolumn{2}{|c|}{ Number of samples } \\
\hline & & & Summer & Winter \\
\hline \multirow[t]{5}{*}{ Salinity hazard $(\mathrm{EC})(\mu \mathrm{S} / \mathrm{cm})$} & $<250$ & Excellent & 0 & 0 \\
\hline & $250-750$ & Good & 2 & 8 \\
\hline & $750-2000$ & Permissible & 13 & 9 \\
\hline & $2000-3000$ & Doubtful & 6 & 6 \\
\hline & $>3000$ & Unsuitable & 3 & 1 \\
\hline \multirow[t]{4}{*}{ Alkalinity hazard (SAR) (Richards 1954) } & $<10$ & Excellent & 23 & 24 \\
\hline & $10-18$ & Good & 1 & 0 \\
\hline & $18-26$ & Doubtful & 0 & 0 \\
\hline & $>26$ & Unsuitable & 0 & 0 \\
\hline \multirow[t]{5}{*}{ Percent sodium (\%Na) (Wilcox 1955) } & $<20$ & Excellent & 6 & 8 \\
\hline & $20-40$ & Good & 10 & 11 \\
\hline & $40-60$ & Permissible & 6 & 4 \\
\hline & $60-80$ & Doubtful & 2 & 1 \\
\hline & $>80$ & Unsuitable & 0 & 0 \\
\hline \multirow[t]{2}{*}{ Magnesium ratio (MR) (Palliwal 1972) } & $>50 \%$ & Suitable & 4 & 6 \\
\hline & $<50 \%$ & Unsuitable & 20 & 18 \\
\hline \multirow[t]{2}{*}{ Corrosivity ratio (CR) (Raman 1985) } & $<1$ & Safe & 10 & 13 \\
\hline & $>1$ & Unsafe & 14 & 11 \\
\hline
\end{tabular}

crops by reducing the soil permeability (Kumar et al. 2007). The SAR values for each water sample were calculated as:

$\mathrm{SAR}=\mathrm{Na}^{+} /\left(\mathrm{Ca}^{2+}+\mathrm{Mg}^{2+}\right)^{1 / 2} / 2 \quad$ (All concentrations expressed in $\mathrm{Meq} / \mathrm{l})$

According to Richards (1954) classification based on SAR values (Table 6), all the samples were found to be suitable for irrigation during both the seasons, and hence no alkali hazard is estimated to the crops.

\section{Sodium percentage $(\% \mathrm{Na})$}

Sodium reacts with soil, thereby reducing its permeability which indicates that sodium concentration is important in the classification of irrigation water quality (Purushothman et al. 2012). When sodium content is high in the irrigation water, it is adsorbed by the clay particles of the soil. This results in exchange of $\mathrm{Na}^{+}$in water and displacing $\mathrm{Ca}^{2+}$ and $\mathrm{Mg}^{2+}$ from soil. The soil permeability decreases with poor internal drainage resulting in limited air and water circulation during wet conditions. When dry, such types of soils become hard (Saleh et al. 1999). Wilcox (1955) proposed a classification based on sodium percentage which can be calculated from the following formula:

$$
\% \mathrm{Na}=\left(\mathrm{Na}^{+}+\mathrm{K}^{+}\right) \times 100 /\left(\mathrm{Ca}^{2+}+\mathrm{Mg}^{2+}+\mathrm{Na}^{+}+\right.
$$
$\mathrm{K}^{+}$) (All ionic concentrations expressed in meq/l)

The results based on $\% \mathrm{Na}$ showed that majority of the samples were found to be good for irrigation (Table 6). No sample falls in unsuitable category during both the seasons. Wilcox (1955) used \% Na and EC to evaluate the quality of water quality using Wilcox diagram (Fig. 3). The analytical data plotted on Wilcox diagram illustrates that except few samples, most of the groundwater samples fall in excellent and good categories and can be used for irrigation.

\section{Magnesium ratio (MR)}

Based on the magnesium ratio, water can be classified as suitable for irrigation purpose, if the MR ratio is greater than $50 \%$ (Palliwal 1972). It is expressed as:

$$
\mathrm{MR}=\left(\mathrm{Mg}^{2+}\right) \times 100 /\left(\mathrm{Ca}^{2+}+\mathrm{Mg}^{2+}\right)
$$

Generally, $\mathrm{Ca}$ and $\mathrm{Mg}$ are present in equilibrium in most of the waters. The quality of soil is affected adversely when magnesium content is high in water, resulting in alkaline nature of the soil and thereby reducing the crop yield (Kumar et al. 2007). Based on MR, most of the samples were unsuitable for irrigation during both seasons (Table 6).

\section{Corrosivity ratio (CR)}

It is expressed as: $\mathrm{CR}=\left[\mathrm{Cl}^{-} / 35.5+2\left(\mathrm{SO}_{4}{ }^{2-} / 96\right)\right] /$ $2\left(\mathrm{HCO}_{3}{ }^{-}+\mathrm{CO}_{3}{ }^{2-} / 100\right)$

The groundwater is considered safe for transport by pipes if corrosivity ratio is less than 1 while the value 
Fig. 3 Water classification on the basis of percent sodium and electrical conductivity (after Wilcox 1955)

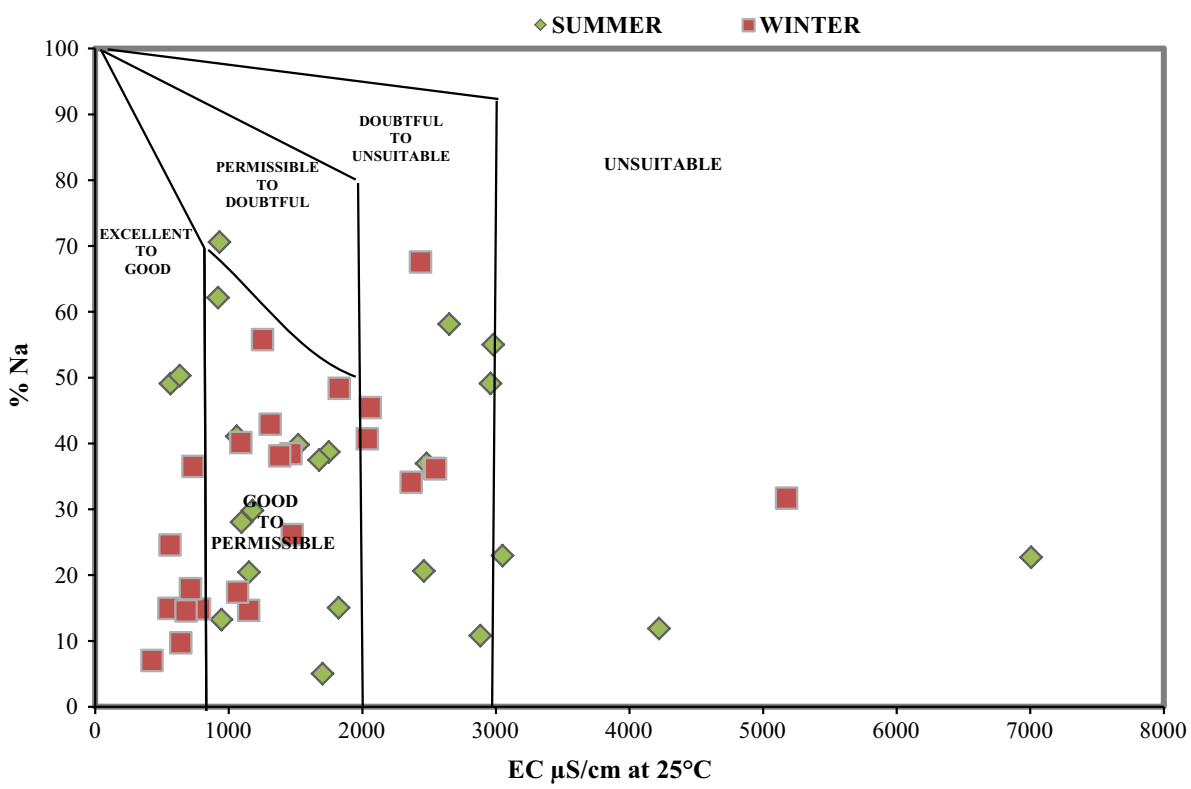

greater than 1 indicates corrosive nature of water (Tripathi et al. 2012). The calculated values of groundwater suggests that out of 24 samples analyzed 14 samples in summer and 11 samples in winter were corrosive in nature (Table 6) and need noncorrosive pipes for transporting and uplifting groundwater.

\section{Hydrochemical facies of groundwater}

The factors influencing the groundwater geochemistry are geochemical reactions and mixing of neighboring samples. The assessment of groundwater is primarily dependent on the relationship between rock types and water composition. Hydrogeochemical facies analysis is a valuable tool for determining the flow pattern and origin of chemical histories of groundwater (Chung et al. 2015). In this study, groundwater has been classified as per Piper trilinear diagram (Piper 1944) to understand the hydrochemical facies of groundwater resources in study area (Fig. 4). Three well defined fields are depicted in the diagram consisting of two triangular and a central diamond shaped field representing the overall characteristics of water (Oki and Akana 2016). The cation triangle shows that the majority of the samples fall in no dominant zone in both the seasons while $\mathrm{HCO}_{3}$ is the dominant ion as depicted by anion triangle of the Piper trilinear diagram. Two major types of hydrogeochemical facies were observed in different aquifers of the study area. The majority of the samples belonged to $\mathrm{Ca}-\mathrm{Mg}-\mathrm{HCO}_{3}$ and $\mathrm{Ca}-\mathrm{Mg}-\mathrm{SO}_{4}-\mathrm{Cl}$ representing temporary hard water and permanently hard water type in both the seasons. The groundwater samples falling in $\mathrm{Mg}-\mathrm{HCO}_{3}$ facies having secondary salinity exceeds $50 \%$ indicates the factors responsible for controlling groundwater chemistry are reverse ion exchange, leaching process of dolomites, limestones and gypsum. The samples that fall in $\mathrm{Ca}-\mathrm{Mg}-$ $\mathrm{SO}_{4}-\mathrm{Cl}$ water type demonstrate $\mathrm{Ca}-\mathrm{Mg}-\mathrm{Cl}$ facies where groundwater cannot be characterized either as cation or anion dominant (Herojeet et al. 2016). The relative hardness of water is attributed to the presence of cations such as calcium and magnesium and anions such as bicarbonate and chlorides. It is clearly evident from the position of data points that alkaline earth $(\mathrm{Ca}+\mathrm{Mg})$ metals exceed alkalies $(\mathrm{Na}+\mathrm{K})$ in 83.3 and $91.6 \%$ of the samples during summer and winter, respectively. The data revealed that carbonate hardness exceeds $50 \%$ in most of the samples indicating chemical properties of water are dominated by alkaline earth and weak acids.

\section{Mechanisms controlling groundwater chemistry}

\section{Gibbs diagram and water-rock interaction}

The groundwater chemistry is a major aspect of determining its use for domestic and irrigation purposes. Chemistry of groundwater is greatly controlled by the interaction of groundwater with aquifer minerals. The contributions of rock/soil-water interaction and anthropogenic influences on groundwater can be studied by various hydrogeochemical processes (Singh et al. 2011). To obtain an insight into hydrogeochemical processes, Gibbs (1970) has proposed scatter diagram method illustrating three important natural mechanisms controlling the major ion chemistry of the groundwater including water-rock interaction, evaporation and atmospheric precipitation. The 


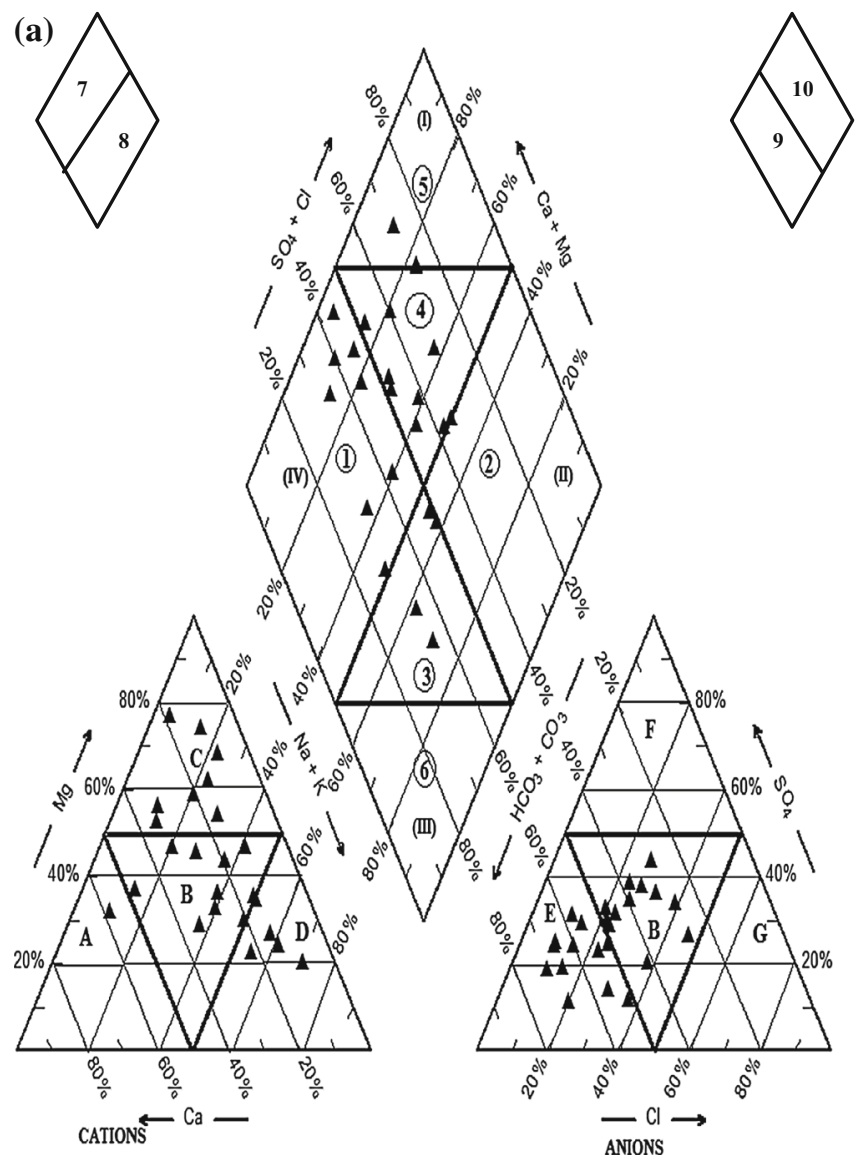

Fig. 4 Geochemical classification of groundwater in Piper diagram. a Summer season. b Winter season. $1 \mathrm{MgHCO}_{3} ; 2 \mathrm{NaCl}$; 3 Mixed $\mathrm{CaNaHCO}_{3} ; 4$ Mixed $\mathrm{CaMgCl} ; 5 \mathrm{CaCl} ; 6 \mathrm{NaHCO}_{3} ; 7$ Alkaline earth $(\mathrm{Ca}+\mathrm{Mg})$ exceed alkalis $(\mathrm{Na}+\mathrm{K}) ; 8$ Alkalis exceed Alkaline Earths; 9 Weak Acids $\left(\mathrm{CO}_{3}+\mathrm{HCO}_{3}\right)$ exceed strong Acids $\left(\mathrm{SO}_{4}+\right.$

TDS concentrations were plotted against the ratios of $\mathrm{Na}+\mathrm{K} /(\mathrm{Na}+\mathrm{K}+\mathrm{Ca})$ for cations and $\mathrm{Cl} /\left(\mathrm{Cl}+\mathrm{HCO}_{3}\right)$ for anions (Fig. 5a-d). It was found that majority of the samples collected from intermediate and deep aquifers falls in rock dominance during both the seasons. This reflected the significance of water-rock interactions as the major source of dissolved ions controlling the chemical composition of these waters ( $\mathrm{Li}$ et al. 2015; Raju et al. 2015). Next to rock dominance, a few groundwater samples fell into evaporation dominant area, signifying the role of evaporation on shallow groundwater chemistry. The dominance of silicate weathering is reflected if bicarbonate and sulfate dominate calcium and magnesium, resulting in increasing the concentration of $\mathrm{HCO}_{3}$ in groundwater (Elango and Kannan 2003). The scatter diagram of $\mathrm{Ca}+\mathrm{Mg}$ vs $\mathrm{HCO}_{3}+\mathrm{SO}_{4}$ (Fig. 6) showed 71 and $88 \%$ samples in summer and winter seasons, respectively, fall below the equiline, indicating the primary process involved in the evolution of groundwater was silicate weathering (Tamma et al. 2015). (b)

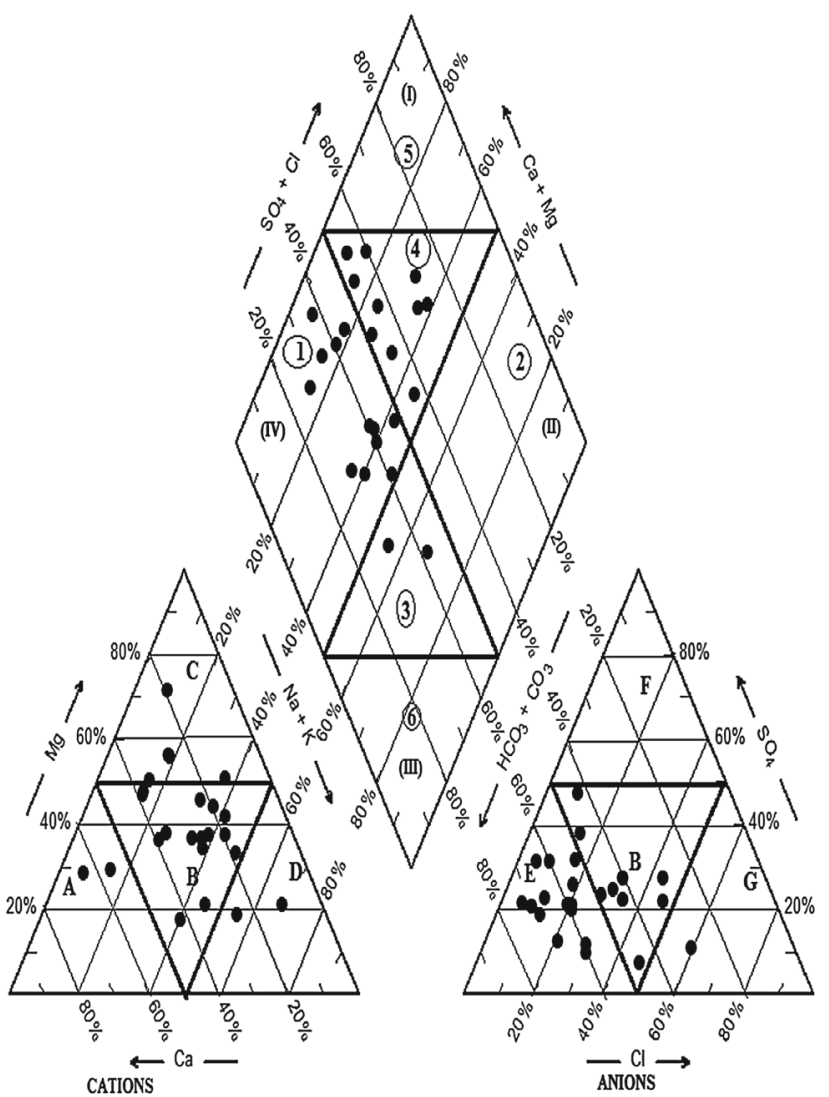

Cl); 10 Strong acids exceeds weak acids; $A$ Calcium type; $B$ No dominant; $C$ Magnesium type; $D$ Sodium type; $E$ Bicarbonate type; $F$ Sulphate type $G$ Chloride type (I) Ca-Mg-Cl-SO $\mathrm{SO}_{4}(I I) \mathrm{Na}-\mathrm{K}-\mathrm{Cl}-\mathrm{SO}_{4}$ (III) $\mathrm{Na}-\mathrm{K}-\mathrm{HCO}_{3}$ (IV) $\mathrm{Ca}-\mathrm{Mg}-\mathrm{HCO}_{3}$

\section{Index of base exchange}

Groundwater undergoes changes in the chemical composition during its travel to the subsurface and ion exchange is one of the important processes to evaluate these changes (Aghazadeh and Mogaddam 2010). Ion exchange occurring between the groundwater and its host environment are indicated by chloro alkaline indices, CAI 1 and CAI 2 as suggested by Schoeller (1977). The ion exchange indices were estimated by the following equations:

Chloro alkaline index $1=(\mathrm{Cl}-(\mathrm{Na}+\mathrm{K})) / \mathrm{Cl}$

Chloro alkaline Index $2=\left(\mathrm{Cl}-(\mathrm{Na}+\mathrm{K}) /\left(\mathrm{SO}_{4}+\right.\right.$ $\mathrm{HCO}_{3}+\mathrm{CO}_{3}+\mathrm{NO}_{3}$ )

In direct exchange, the indices are positive which indicates ion exchange of $\mathrm{Na}^{+}$and $\mathrm{K}^{+}$from water occurs with $\mathrm{Mg}$ and $\mathrm{Ca}$ in the rock. During indirect exchange, the ion exchange occurs in reverse order and the indices are found to be negative. CAI 1 and 2 calculated for both seasons revealed $75 \%$ of the summer samples and $96 \%$ of winter samples showed a negative ratio indicating the dominance 
Fig. 5 Gibbs diagram for mechanism controlling groundwater chemistry; a Gibbs ratio (cations) during summer season; b Gibbs ratio (anions) during summer season; c Gibbs ratio (cations) during winter season; d Gibbs ratio (anions) during winter season
Fig. 6 Plot of $\mathrm{Ca}+\mathrm{Mg}$ versus $\mathrm{HCO}_{3}+\mathrm{SO}_{4}$ for both summer and winter season
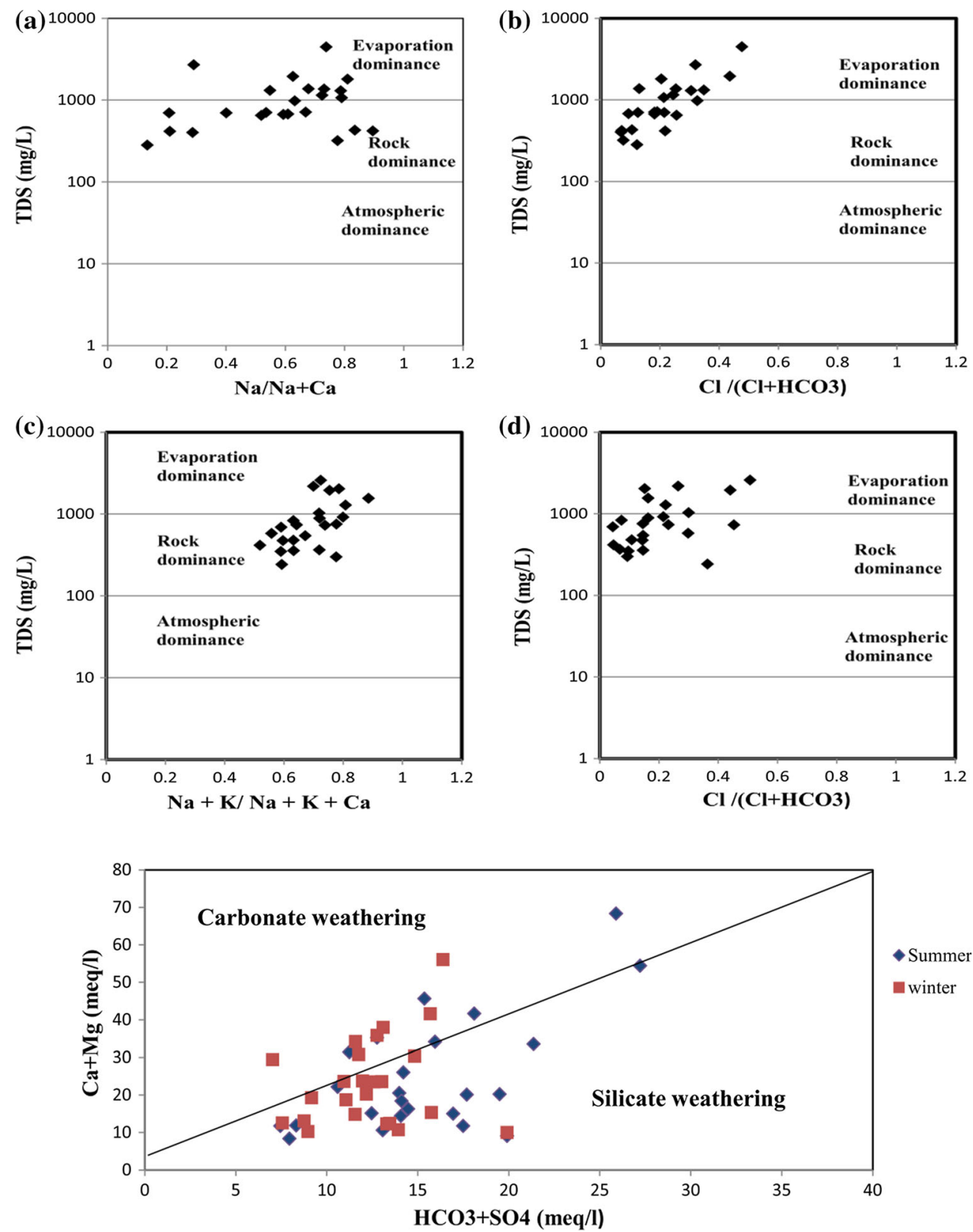

of reverse ion exchange. An increase in indirect exchange was observed during winter as compared to summer season. $25 \%$ of the samples showed a significant switch over between ion and reverse ion exchange on seasonal basis.

\section{Saturation index (SI)}

Geochemical modeling was done by aquachem software to evaluate the mineral saturation indices. Saturation index is important to determine the degree of equilibrium between water and minerals and to recognize mineral dissolution and precipitation processes in the aquifers (Redwan et al. 2016). Following equation is used to compute the saturation index:
$\mathrm{SI}=\log \mathrm{IAP} / \mathrm{K}_{\mathrm{sp}}=\log \mathrm{IAP}-\log \mathrm{K}_{\mathrm{sp}}$

where IAP is the ion activity product and $\mathrm{K}_{\mathrm{sp}}$ is the solubility product constant. The mineral is saturated or supersaturated with respect to the solution when the saturation index is positive and its tendency to precipitate in groundwater. Negative value of SI suggests that water is undersaturated with respect to the mineral indicating dissolution of mineral in the system. The mineral is in equilibrium with groundwater in contact when SI value is 0 and has no tendency to precipitate or dissolve in groundwater. The assessment of SI might be helpful to understand the geochemical processes occurring in the region and would be able to determine the origin of dissolved ions in groundwater (Kumar and Singh, 2015). The values of SI for calcite and 
Fig. 7 Saturation indices for calcite and aragonite in the groundwater samples. a Calcite $\mathrm{SI}$ versus $\mathrm{Ca}+\mathrm{HCO}_{3}$ (Summer season). b Calcite SI versus $\mathrm{Ca}$ $+\mathrm{HCO}_{3}$ (Winter season). c Aragonite SI versus $\mathrm{Ca}+\mathrm{HCO}_{3}$ (Summer season). d Aragonite $\mathrm{SI}$ versus $\mathrm{Ca}+\mathrm{HCO}_{3}$ (Winter season)
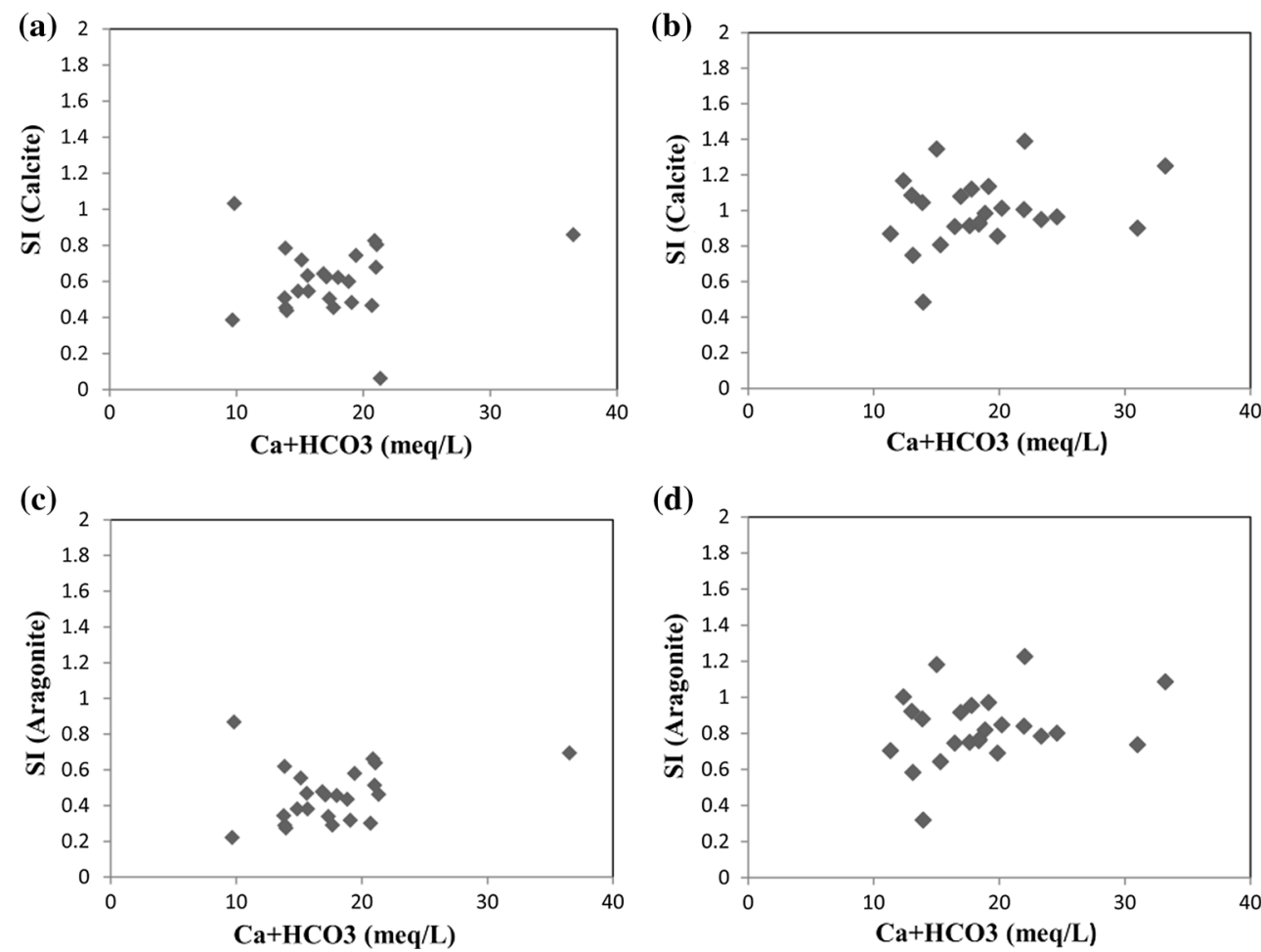

(d)

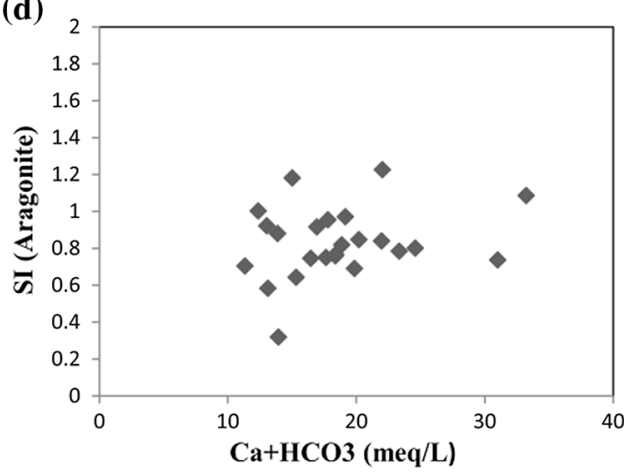

aragonite were plotted in Fig. 7a-d located in the system. Carbonate minerals are supersaturated in the aquifers and incapable of dissolving more of minerals as the values of SI are greater than 0 in all the samples. The factors such as incongruent weathering of carbonate mineral and silicate minerals dissolution, common ion effect, and evaporation, temperature and carbon dioxide exsolution, infiltration of wastewater and irrigation return flows from nearby agricultural areas may have contributed to the saturation or supersaturation of the carbonate minerals (Aghazadeh and Mogaddam 2010; Redwan et al. 2016; Jabal et al. 2015).

\section{Conclusions}

The hydrochemical analysis of the study area in parts of Malwa region, Punjab (India) reveals that the groundwater is highly contaminated except for a few locations. The majority of water samples were found to be beyond desirable limits as prescribed by WHO standards and Indian standards for drinking water. Samples from almost all the locations were classified as hard and contained high TDS which indicate its unsuitability for drinking. A wide variation in EC and TDS is observed in samples during both the seasons indicating the influence of climatic factors including rock water interaction as well as anthropogenic activities, such as increase in pumping, excessive use of fertilizers, and discharge of industrial effluents on the hydrochemistry of the study area. The abundance of major cations and anions found during both the seasons was $\mathrm{Na}^{+}>\mathrm{Ca}^{2+}>\mathrm{Mg}^{2+}>\mathrm{K}^{+}$and $\mathrm{HCO}_{3}>\mathrm{SO}_{4}{ }^{2-}>\mathrm{Cl}^{-}$, respectively. Among the different parameters analyzed, it was seen that EC, total hardness, alkalinity, calcium, sulfates and fluorides were higher than the BIS permissible limits in most of the samples. High level of fluoride is a major cause of concern. The total arsenic content in groundwater samples was higher than the safe limits of $10 \mu \mathrm{g} / \mathrm{L}$ set by WHO and BIS making water unsuitable for drinking purpose. Excessive use of phosphate fertilizer which is a common practice in this region seems to be the major anthropogenic sources of arsenic in the water samples. The groundwater falls in permissible range based on salinity hazard except few locations. However, the salinity hazard is quite high even though the alkalinity hazard is low. The high level of Iron was observed in groundwater, but no significant correlation was found between arsenic and iron. The parameters like sodium adsorption ratio (SAR), sodium percentage, and magnesium ratio were calculated from the chemical data. As per the results obtained, SAR and $\mathrm{Na} \%$ revealed good quality of groundwater for irrigation purposes, whereas, MR and CR values showed that this water is not suitable for agriculture and domestic use. The area having corrosive ratio more than one need noncorrosive pipes for water supply. As for hydrochemical facies, Piper (1944) diagram suggested majority of the samples belonged to $\mathrm{Ca}-\mathrm{Mg}-\mathrm{HCO}_{3}$ and $\mathrm{Ca}-\mathrm{Mg}-\mathrm{SO}_{4}-\mathrm{Cl}$ representing temporary hard water and permanently hard water type in both the seasons. The 
majority of samples fall in rock dominance zone followed by few samples from shallow region felling in evaporation dominance zone according to Gibbs (1970) plot indicating that the lithology plays a significant role in controlling the overall quality of groundwater apart from various other local environmental conditions. Chloro alkaline index 1 and 2 indicates the dominance of reverse ion exchange during both the seasons. The results of geochemical modeling showed that groundwater samples were supersaturated with respect to carbonate minerals. From this study, it is concluded that groundwater in the study area is chemically unsuitable for domestic and agricultural uses, but more intensive work and detailed analysis of heavy metals and other organic pollutants is required to obtain conclusive results. The affirmative solution will be a continuous water quality monitoring program and a detailed hydrogeochemical investigation is suggested for sustainable utilization of water resources not only in the study area, but in the entire state of Punjab. Finally, it is concluded that there is lack of proper monitoring of water quality, and a regular chemical analysis is required to check the suitability of water for drinking and irrigation purpose.

Acknowledgments The authors thank financial support of University Grants Commission (UGC), New Delhi and Guru Nanak Dev University, Amritsar. Authors are thankful to UPE (under the university with potential for excellence), BSR and CPEPA programme. The funders had no role in study design, data collection and analysis, decision to publish, or preparation of the manuscript.

\section{Compliance with ethical standards}

Conflict of interest The authors declare that they have no competing interests.

Open Access This article is distributed under the terms of the Creative Commons Attribution 4.0 International License (http:// creativecommons.org/licenses/by/4.0/), which permits unrestricted use, distribution, and reproduction in any medium, provided you give appropriate credit to the original author(s) and the source, provide a link to the Creative Commons license, and indicate if changes were made.

\section{References}

Aghazadeh N, Mogaddam AA (2010) Assessment of groundwater quality and its suitability for drinking and agricultural uses in the Oshnavieh area, Northwest of Iran. J Environ Prot 1:30-40

Alemu ZA, Teklu KT, Alemayehu TA, Balcha KH, Mengesha SD (2015) Physicochemical quality of drinking water sources in Ethiopia and its health impact: a retrospective study. Environ Syst Res 4:22

APHA (1985) Standard methods for examination of water and wastewater, 20th edn. American Public Health Association, Washington, DC

Azizullah A, Khan Khattak MN, Richter P (2011) Water pollution in Pakistan and its impact on public health-a review. Environ Int 37:479-497
Baig JA, Kazia TG, Muhammad Balal Arain MB, Afridi HI, Kandhro GA, Sarfraza RA, Jamal MK, Shah AQ (2009) Evaluation of arsenic and other physicochemical parameters of surface and ground water of Jamshoro, Pakistan. J Hazard Mater 166:662-669

Bajwa BS, Kumar S, Singh S, Sahoo SK, Tripathi RM (2015) Uranium and other heavy toxic elements distribution in the drinking water samples of SW-Punjab, India. J Radiat Res Appl Sci 1-9. doi:10.1016/j.jrras.2015.01.002

BIS (1991) Specification for drinking water (IS 10500: 1991)

Central Ground Water Board (2007) Ministry of water resources, Government of India, North Western Region, Chandigarh Bathinda district, Punjab

Chakraborti D, Rahman MM, Ahamed S, Dutta RN, Pati S, Mukherjee SC (2016) Arsenic contamination of groundwater and its induced health effects in Shahpur block, Bhojpur district, Bihar state, India: risk evaluation. Environ Sci Pollut Res. doi:10.1007/s11356-016-6149-8

Chung SY, Venkatramanan S, Kim TH, Kim DS, Ramkumar T (2015) Influence of hydrogeochemical processes and assessment of suitability for groundwater uses in Busan City, Korea. Environ Dev Sustain 17:423-441

Craig E, Anderson MP (1979) The effects of urbanization of ground water quality. A case study of ground water ecosystems. Environ Conserv 30(2):104-130

Elango L, Kannan R (2003) Rock-water interaction and its control on chemical composition of groundwater, Chap. 11. Dev Environ Sci 5:229-243

Gibbs RJ (1970) Mechanisms controlling World's water chemistry. Science 170:108

Government of India Planning Commission (2013) Report of the high level expert group on water logging in Punjab

Handa BK (1975) Geochemistry and genesis of fluoride containing groundwater in India. Groundwater 13(3):275-281

Herojeet R, Rishi MS, Lata R, Sharma R (2016) Application of environmetrics statistical models and water quality index for groundwater quality characterization of alluvial aquifer of Nalagarh Valley, Himachal Pradesh, India. Sustain Water Resour Manag 2:39-53

Hundal HS, Kumar R, Singh K, Singh D (2007) Occurrence and geochemistry of arsenic in groundwater of Punjab, Northwest India. Commun Soil Sci Plan 38(17-18):2257-2277

Hundal HS, Singh K, Singh D (2008) Arsenic content in ground and canal waters of Punjab, North-West India. Environ Monit Assess. doi:10.1007/s10661-008-0406-3. http://www. springerlink.com/content/x270834403h412h8/ Accessed 10 Dec 2008

Jabal MSA, Abustan I, Rozaimy MR, El Najar H (2015) Groundwater beneath the urban area of Khan Younis City, southern Gaza Strip (Palestine): hydrochemistry and water quality. Arab J Geosci 8:2203-2215

Jain CK, Bandyopadhyay A, Bhadra A (2010) Assessment of groundwater quality for drinking purpose, district Nainital, Uttarakhand, India. Environ Monit Assess 166:663-676

Kumar A, Singh CK (2015) Characterization of hydrogeochemical processes and fluoride enrichment in groundwater of southwestern Punjab. Water Qual Expo Health 7:373-387

Kumar M, Kumari K, Ramanathan AL, Saxena R (2007) A comparative evaluation of groundwater suitability for irrigation and drinking purposes in two intensively cultivated districts of Punjab, India. Environ Geol 53:553-574

Kumar M, Kumari K, Singh UK, Ramanathan AL (2009) Hydrogeochemical processes in the groundwater environment of Muktsar, Punjab: conventional graphical and multivariate statistical approach. Environ Geol 57:873-884 
Kumar P, Kumar M, Ramanathan A, Tsujimura M (2010) Tracing the factors responsible for arsenic enrichment in groundwater of the middle Gangetic Plain, India: a source identification perspective. Environ Geochem Health 32:129-146

Li C, Gao X, Wang Y (2015) Hydrogeochemistry of high-fluoride groundwater at Yuncheng Basin, northern China. Sci Total Environ 508:155-165

Memon AH, Ghanghro AB, Jahangir TM, Lund GM (2016) Arsenic contamination in drinking water of District Jamshoro, Sindh, Pakistan. Biomed Lett 2(1):31-37

Miller GT (1979) Living in the environment. Wordsworth Publishing company, California, p 470

Oki AO, Akana TS (2016) Quality assessment of groundwater in Yenagoa, Niger Delta, Nigeria. Geosciences 6(1):1-12

Palliwal KV (1972) Irrigation with saline water, ICARI Monograph No.2, New Delhi, p 198

Piper AM (1944) A graphic procedure in the geochemical interpretation of water analysis [M]. Trans Am Geophys Union 25:914-923

Purushothman P, Rao MS, Kumar B, Rawat YS, Krishan G, Gupta S, Marwah S, Bhatia AK, Kaushik YB, Angurala MP, Singh GP (2012) Drinking and irrigation water quality in Jalandhar and Kapurthala Districts, Punjab, India: using hydrochemistry. IJEE 5(6): 1599-1608

Raju NJ, Patel P, Gurung D, Ramb P, Gossel W, Wycisk P (2015) Geochemical assessment of groundwater quality in the Dun valley of central Nepal using chemometric method and geochemical modeling. Groundw Sustain Dev 1:135-145

Raman V (1985) Impact of corrosion in the conveyance and distribution of water. J IWWA 11:115-121

Rasool A, Xiao T, Farooqi A, Shafeeque M, Liu Y, Kamran MA, Katsoyiannis IA, Eqani SAMAS (2016) Quality of tube well water intended for irrigation and human consumption with special emphasis on arsenic contamination at the area of Punjab, Pakistan. doi:10.1007/s10653-016-9855-8

Redwan M, Moneim AAA, Amra MA (2016) Effect of water-rock interaction processes on the hydrogeochemistry of groundwater west of Sohag area, Egypt. Arab J Geosci 9:111. doi:10.1007/ s12517-015-2042-x

Richards LA (1954) Diagnosis and improvement of saline and alkali soils. Agri. Handbook 60. U.S. Department of Agriculture, Washington, DC, p 160

Saleh A, Al-Ruwaih F, Shehata M (1999) Hydrogeochemical processes operating within the main aquifers of Kuwait. J Arid Environ 42:195-209
Sayyed JA, Bhosle AB (2011) Analysis of Chloride, Sodium and Potassium in groundwater samples of Nanded City in Mahabharata, India. Eur J Exp Biol 1(1):74-82

Schoeller H (1977) Geochemistry of groundwater. Groundwater studies - an international guide for research and practice. UNESCO, Paris, pp 1-18

Sharma R (2012) Analysis of water quality parameters of groundwater in Malwa region, Bathinda, India. IJAST 1(11):1-7

Sidhu M, Mahajan P, Bhatt SM (2014) Highly sensitive and low cost colorimetric method for quantifying arsenic metal in drinking water of Malwa Punjab and comparison with ICAP-AES. Ann Biol Res 5(3):105-109

Singh P, Saharan JP, Sharma K, Saharan S (2010) Physio-chemical \& EDXRF analysis of groundwater of Ambala, Haryana, India. Researcher 2(1):68-75

Singh K, Hundal HS, Singh D (2011) Geochemistry and assessment of hydrogeochemical processes in groundwater in the southern part of Bathinda district of Punjab, northwest India. Environ Earth Sci 64:1823-1833

Subramani T, Elango L, Damodarasamy SR (2005) Groundwater quality and its suitability for drinking and agricultural use in Chithar River Basin, Tamil Nadu, India. Environ Geol 47:1099-1110

Tamma RG, Srinivasa RY, Mahesh J, Surinaidu L, Dhakate R, Gurunadha RVVS, Durga PM (2015) Hydrochemical assessment of groundwater in alluvial aquifer region, Jalandhar District, Punjab, India. Environ Earth Sci 73:8145-8153

Thakur T, Rishi MS, Naik PK, Sharma P (2016) Elucidating hydrochemical properties of groundwater for drinking and agriculture in parts of Punjab, India. Environ Earth Sci 75:467

Thivya C, Chidambaram S, Rao MS, Thilagavathi R, Prasanna MV, Manikandan S (2015) Assessment of fluoride contaminations in groundwater of hard rock aquifers in Madurai district, Tamil Nadu (India). Appl Water Sci. doi:10.1007/s13201-015-0312-0

Tripathi AK, Mishra UK, Mishra A, Tiwari S, Dubey P (2012) Studies of hydrogeochemical in groundwater quality around Chakghat Area, Rewa District, Madhya Pradesh, India. Int J Mod Eng Res Technol 2(6):4051-4059

Wenzel WW, Blum WEH (1992) Fluoride speciation and mobility in fluoride contaminated soil and minerals. J Soil Sci 153:357-364

WHO (2004) Guideline for drinking water quality, 3rd edn. Recommendation World Health Organization, Geneva

Wilcox LV (1955) Classification and use of irrigation waters. U.S. Department of Agriculture. Circ, Washington, DC, p 969 